Murjito dkk.Magang Kewirausahaan Pada Industri Jasa.

\title{
MAGANG KEWIRAUSAHAAN PADA INDUSTRI JASA PERAWATAN DAN PENJUALAN SUKU CADANG KENDARAAN BERMOTOR DI YAMAHA DAU MOTOR
}

\author{
W. Murjito, M.T ${ }^{1)}$ \\ W. Ali Mokhtar, M.T ${ }^{2)}$
}

\section{Ringkasan}

Tuntutan lulusan perguruan tinggi di Era teknologi saat ini tidak hanya menguasai teori tetapi harus menguasai praktek di lapangan guna menjawab keterbatasan lapangan pekerjaan yang sudah mencakup semua aspek kehidupan. Oleh karena itu fakultas Teknik UMM sangat bertanggung jawab untuk mencetak lulusan ang menguasai ilmu pengetahuan sekaligus ketrampilan.

Alumni Fakultas Teknik UMM rata-rata menunggu 1-2 tahun untuk masuk dunia kerja dan 15\% dari alumni tersebut berwirausaha, karna mereka rata-rata aktif magang di beberapa industri jasa perbengkelan sewaktu mereka aktif kuliah. Melihat fenomena tersebut,disikapi dengan menadakan program magang kewirausahaan dengan target menghasikan lulusan yang siap bekerja keras sekaligus membentuk kewirausahaan calon alumni.

Melihat kebutuhan dan prospek kedepan,maka program magang ini dilakukan di YAMAHA MOTOR DAU di jalan raya sengkaling No.9 kabupaten malang yang diikuti oleh 10 orang mahasiswa peserta yang telah lulus seleksi dari 25 orang calon pemula.Pelaksanaan magang ini di bagi dalam 3 tahap yaitu: persiapan, pelaksanaan dan evaluasi serta tindak lanjut. Dari 10 orang peserta modal mengikuti program kewirausahaan ini menyatakan bahwa :

1. Mereka mendapatkan banyak hal-hal baru di lapangan dan ketrampilan mereka meningkat

2. Mereka memiliki cukup pengetahuan dan ketrampilan tentang cara perawatan otomotif dan penelolaan usaha bengkel

3. Sebagian peserta berminat usha bengkel / perawatan mesin mendidik yang membuat lembaga pelatihan otomotif. Diharapkan pengetahuan dan pengalaman dari peserta selama magang dapat menjadi alternatif dalam membuka kesempatan kerja bidang otomotif dan bermanfaat bagi tenaga kerja yang masih belum bekerja.

\footnotetext{
1) 2) Staf Pengajar Fakultas Teknik UMM
} 
Jurnal Dedikasi Volume 7, Mei 2010

\section{A.PENDAHULUAN}

\section{Dasar Pemikiran Yang Mendasari Kegiatan Magang}

Semakin bertambah pesatnya jumlah penduduk dan jumlah kendaraan bermontor, maka semakin banyak pula yang membutuhkan perawatan kendaraan bermontor tersebut oleh karena itu perlu diikuti pula banyaknya jasa perawatan perbengkelan sekaligus penjualan suku cadangnya, sehingga mahasiswa Fakultas Teknik sangat cocok untuk diterjunkan pada kegiatan magang kewirausahaan. Beberapa kegiatan yang akan dilakukan dalam magang diantaranya identifikasi permasalahan, analisis dan alternatif penyelesaian masalah, menejemen pengelolaan usaha.

Selama mengikuti magang ini mahasiswa terjun langsung ikut bekerja sehingga mampu menciptakan link and match antara teori dan praktek dilapangan dengan dibimbing oleh staf pengajar yang berpengalaman dalam perawatan dan menejemen pemasaran suku cadang. Dengan demikian mahasiswa akan berpengalaman dan menguasai perawatan dan menejemen pemasaran, yang nantinya sebagai bekal berwirausaha dalam perawatan dan penjualan cuku cadang.

\section{Analisis Situasi Dengan Kegiatan Kewirausahaan}

Tuntutan sarjana lulusan perguruan tinggi di era globalisasi tidak hanya menghasilkan lulusan yang menguasai teori, tetapi harus menguasai praktek di lapangan. Sehingga perlu disiapkan calon alumni yang mampu menguasai ilmu pengetahuan sekaligus ketrampilanFakultas Teknik Universitas Muhammadiyah Malang yang telah berdiri tahun 1978 telah menghasilkan sekitar 7500 lulusan sarjana dengan jumlah rata rata wisudawan 360 orang pertahun. Hasil polling alumni dari jumlah lulusan tersebut hanya $15 \%$ yang langsung berwirausaha sesuai dengan bidang ilmu, sedangkan sisanya menunggu 1 sampai 2 tahun untuk mencari lowongan pekerjaan. Dari 15\% yang berwirausaha rata - rata karena mereka aktif selama liburan kuliah untuk magang di beberapa industri jasa perbengkelan yang bergerak dalam bidang perawatan dan jual suku cadang mesin.

Fenomena ini disikapi dengan mengadakan program Magang Kewirausahaan (MKU), dengan target dan tujuan akan menghasilkan mahasiswa yang siap bekerja keras, tekun dan giat sekaligus membentuk jiwa kewirausahaan di kalangan kampus. Dari sini nantinya akan dikembangkan sendiri oleh peserta magang tersebut sebagai bekal ketika mereka sudah selesai kuliah.

Program magang kewirausahaan bagi calon sarjana Teknik sangat penting, pada era globalisasai ekonomi dan perdagangan, sehingga pada akhirnya dituntut calon-calon wirausahawan yang ulet dan tangguh. Adapaun tempat magang kewirausahaan mahasiswa ini pada Bengkel YAMAHA DAU MOTOR dengan alamat Jl. Raya Sengkaling No. 9 Dau - Malang Jawa Timur, tempat ini dipilih karena tempatnya cukup strategis, mudah dijangkau dan prospek perkembangannya cukup baik, bagi dosen dan mahasiswa sangat mudah transportasinya. 
Murjito dkk.Magang Kewirausahaan Pada Industri Jasa.

\section{Tujuan Kegiatan}

\subsection{Tujuan Umum :}

- Memberikan pengalaman praktis kewirausahaan kepada mahasiswa dengan cara ikut serta sehari-hari sebagai bagian integral pada suatu bengkel perawatan dan menjual suku cadang.

- Mengenal metode yang dilakukan baik dari aspek teknologi perawatan maupun sistem organisasi yang diterapkan

- Memahami permasalahan yang dihadapi dan cara mengatasi permasalahan

- Berkembangnya sifat kreatif dan inovatif mahasiswa untuk bergerak di bidang wirausaha

- M e n i n g k a t k a n kemampuan untuk menerapkan pengetahuan dan keterampilan yang dimiliki

- M e n i n g k a t k a n kemampuan berorganisasi dan bersosialisasi dengan sistem menejemen yang dilakukan industri jasa tersebut

\subsection{Tujuan Khusus :}

- Mampu menguasai dan menerapkan teknik-teknik perbengkelan

- Menguasai dan menghapalkan semua komponen suku cadang kendaraan bermotor di tempat magang.

- Mampu dan menguasai teknik pemasaran suku cadang kendaraan bermotor di tempat magang.

- Mampu kerkomunikasi dengan para konsumen di tempat magang.

\section{Target Luaran}

- Mampu membuat proposal rencana kewirausahaan

- Mampu membuat dan merancang usaha perbengkelan

- Mampu berwirausaha dimana mereka berada setelah ikut magang.

- Membentuk minimal 1 atau 2 wirausaha baru dalam bidang perbengkelan

- Adanya kerjasama yang baik dimana masing masing pihak bisa mengembangkan secara matang sesuai dengan prestasi yang dimiliki kedua belah pihak yaitu antara pihak perusahaan dan pihak perguruan tinggi. 
Jurnal Dedikasi Volume 7, Mei 2010

\section{Manfaat Magang Kewirausahaan}

(MKU)

5.1. Manfaat bagi mahasiswa peserta magang

a. Mampu mengidentifikasi permasalahan yang ada mulai dari model pelayanan perawatan, penjualan suku cadang.

b. Mampu menganalisis dan memecahkan masalah perawatan kendaraan dan system penjualan suku cadang

c. Mengetahui perkembangan perawatan peralatan kendaraan dan suku cadang kendaraan.

d. Mampu menangani menejemen perawatan dan penjualan suku cadang.

e. Mampu membuat rencana usaha jasa peratawan dan penjualan suku cadang kendaraan bermotor.

\subsection{Manfaat bagi Mitra}

a. Mendapatkan masukan dari Perguruan Tinggi tentang kekurangan dan kelemahan system kemitraan usaha jasa perawatan,

b. Mendapatakan masukan system menejemen perawatan yang cocok baik dan benar

\subsection{Manfaat bagi Tim Pelaksana} (Perguruan Tinggi)

a. Mendapatkan pengalaman prakatis berwirausaha serta menemukan akses usaha pada jasa perawatan dan penjualan suku cadang kendaraan bermotor

b. Menjalin kerjasama lanjutan dan mengadakan pelatihan, penelitian serta menciptakan peluang bisnis dengan jasa perawatan dan penjualan suku cadang kendaraan bermotor

\section{Indikator Keberhasilan Kegiatan}

Keberhasilan program MKU dapat dilihat dari beberapa hal sebagai berikut:

a. Mahasiswa Peserta MKU

- $\quad \mathrm{M}$ a h a s i w a peserta program magang dapat pengetahuan tentang teknik otomotif dan perawatannya.

- Mahasiswa dapat penge tahuan kapan sepeda harus dirawat dan diservis.

- Mahasiswa dapat pengetahuan tentang kapan kendaraan harus ganti spare part dan oli

- Mahasiwa dapat b a g a i m a n a menjual spare part/ suku cadang dan kodekodenya.

- $\quad \mathrm{M}$ a h a s i s w a mempunyai jiwa wirausahawan

\section{b. Unit Bisnis Mitra}

- $\mathrm{D} \quad \mathrm{a} \quad \mathrm{p} \quad \mathrm{a} \quad \mathrm{t}$ 
Murjito dkk.Magang Kewirausahaan Pada Industri Jasa.

omset penjualan

dan pelanggan

- D a $\mathrm{p}$ a $\mathrm{t}$ meningkatkan kualitas tenaga kerja dan mekanik

- D a $\mathrm{p}$ a $\mathrm{t}$ mempertahankan cash flow

- $\mathrm{D}$ a $\quad \mathrm{p}$ a $\mathrm{t}$ meningkatkan jangkauan pasar

\section{c. Perguruan Tinggi Penyelenggara MKU}

- J u m l a h mahasiswa yang terlibat dalam MKU 10 Orang

- Mahasiswa peserta dapat pengetahuan interprener sip/ kewirausahaan

- D a $p$ a $\mathrm{m}$ e $\mathrm{nu} \mathrm{mbuh}$ kembangkan b u d a y a kewirausaan di $\mathrm{k}$ a l a n g a $\mathrm{n}$ mahasiswa untuk m e n d orong terciptanya wirausaha baru

\section{B. PELAKSANAAN KEGIATAN 1. Analisis Situasi Mahasiswa Peserta Kegiatan}

Sebelum peserta dikirim untuk melakukan magang, peserta menjalani beberapa tahap seleksi untuk mengetahui kemampuan dari masing-masing peserta, diantaranya test psikologi dan test pengetahuan dasar otomotif. Dari pelaksanaan ini akan diketahui mana peserta yang benar-benar lolos, merupakan hasil seleksi dari test tersebut untuk dikirim ditempat magang, yang mana dari seleksi tersebut akan menghasilkan peserta yang benar-benar ahli dibidang tersebut. Hal ini untuk lebih mempermudah jalannya kegiatan ditempat magang yang mana instruktur ditempat tersebut hanya mengajari cara perawatan mesin serta proses pelayanan pada konsumen.

Program magang kewirausahaan ini dilakukan di sebuah Bengkel yang bergerak di bidang Perawatan dan penjualan suku cadang kendaraan bermotor. Mahasiswa yang dilibatkan dalam pelaksanaan kegiatan magang kewirausahaan ini adalah mahasiswa Fakultas Teknik yang berjumlah 10 orang. Bidang ini diambil karena kebutuhan akan kesediaan jasa perawatan dan penjualan suku cadang kendaraan bermotor cukup tinggi. Magang kewirausahaan ini merupakan awal bagi peserta untuk membuka usaha yang sama dengan melihat peluang yang ada.

$$
\text { Pengalaman dalam dunia }
$$
wirausaha memang menjadi hal yang masih baru bagi mahasiswa. Dengan tidak berbekal pengalaman tentang kewirausahaan hanya berbekal secara teoritis menjadi sebuah tantangan tersendiri bagi mahasiswa yang berminat untuk menggeluti dunia wirausaha. 
pendiri industri jasa perawatan mitra yang kaya dengan pengalaman dibidang jasa perawatan kendaraan dan penjualan suku

\section{Analisis Situasi Industri Kecil Mitra} (IKM)

Mengingat semakin tingginya jumlah kendaraan khususnya sepeda motor 25 juta atau hampir tiap orang mempunyai sepeda motor serta semakin minimnya lapangan pekerjaan yang tersedia. Bagi seorang yang mempunyai kemauan untuk bekerja hal ini merupakan tantangan yang harus segera diselesaikan dengan membuka wirausaha. Ketika negara sedang mengalami krisis multi dimensi, banyak orang di PHK, pengangguran dimana-mana, hanya beberapa persen saja yang bertahan, itu karena tekad dan kondisi berani membuka lapangan kerja sendiri atau berani berwirausaha.

Hal-hal yang mendorong untuk usaha meliputi :

- Keberanian untuk menanggung resiko

- Ulet dalam menghadapi masalah dalam hidup dan tidak putus asa

- Tekun untuk mencari solusi dari segala resiko yang muncul

- Kejelian untuk mencari peluang-peluang bisnis

- Ketekunan dalam berbisnis

Dilihat dari latar belakang pendiriannya, Industri Jasa Perawatan merupakan hasil dari kerja keras pendirinya yang berupaya untuk menjadikan industrinya bisa berkembang sampai saat ini. Disamping itu berpijak pada pengalaman cadang, sebelumnya sudah banyak pengalaman yang menempa hidupnya.

Dari kehidupan yang begitu kerasnya, sang pendiri jasa perawatan tersebut semakin ulet dibidangnya. Diiringi dengan berkembangnya dunia otomotif, industri jasa ini terus berbenah diri menyesuaikan perkembangan yang ada. Keinginan untuk melayani pelanggan dengan sebaik mungkin dengan memperhatikan kualitas dan tepat waktu membuat industri jasa mitra ini membutuhkan tenaga kerja guna menyelesaikan order yang ada tentunya sebuah lapangan kerja baru telah tercipta, berikut ini profil industri jasa perawatan dan penjualan suku cadang yang ada :

\section{a. Bidang Usaha}

Industri jasa ini bergerak di bidang perawatan dan penjualan suku cadang kendaraan bermotor. Untuk mengembangkan usahanya industri ini menerapkan pola kerjasama bisnis kemitraan dengan beberapa industri jasa yang lain juga instansi pemerintah maupun swasta yang banyak mempunyai kendaraan bermotor, setiap hari tidak kurang 50 sapai 60 kendaraan bermotor yang bisa ditangani oleh begkel ini, sedangkan omset tiap hari tidak kurang dari 1 sampai 2 juta.

\section{b. Sumberdaya}

Sumberdaya yang dimiliki industri jasa ini meliputi bangunan terdiri daru dua lantai yang terdiri dari :
$\Rightarrow \quad$ Ruang proses perawatan service
$\Rightarrow \quad$ Cuci kendaraan 
$\Rightarrow \quad$ Ruang penjualan suku cadang

$\Rightarrow \quad$ Ruang penjualan minyak pelumas

dan fasilitas penunjang diantaranya Telepon, kompresor, Drilling, beberapa set peralatan service, gudang dan karyawan. Industri jasa ini berkantor di Jl. Raya Sengkaling No. 9 Kecamatan Dau Kabupaten Malang. dengan jumlah karyawan tetap 10 orang.

\section{c. Kondisi Manajemen}

Dalam menjalankan kegiatan usahanya jasa ini memiliki beberapa divisi yaitu pemilik sekaligus manager perusahaan, pemasaran, reapair dan administrasi. Pimpinan memiliki tugas membuat dan mengatur kebijakan perusahaan. Bagian pemasaran bertugas menyelenggarakan penjualan suku cadang. Bagian repair bertugas memperbaiki alat - alat perawatan yang rusak. Bagian administrasi bertugas mengurus administrasi, karyawan dan keuangan.

Dalam menjalankan aktivitas bisnisnya, industri ini juga menjalankan fungsi sosial dengan memberikan kesempatan dan bimbingan kepada pelajar dan mahasiswa untuk praktek magang dan penelitian.

\section{d. Kondisi pemasaran}

Industri jasa ini terletak di daerah strategis yaitu dilalui jalan propinsi, dimana banyak kendaraan umum maupun pribadi yang selama 24 jam penuh lalu lalang di depan bengkel ini, sehingga dari segi pemasaran cukup strategis, rata-rata setiap hari dapat melayani 50 sampai 60 kendaraan bermotor dengan berbagai keluhan kerusakan yang memanfatakan bengkel ini, juga penjualan suku cadang dan minyak pelumas dari berbagai merk.

\section{Pelaksanaan Kegiatan MKU}

Kegiatan magang kewirausahaan

ini dilaksanakan dengan melakukan kerjasama dengan perusahaan atau industri jasa perawatan dan instruktur yang ahli dibidangnya. Secara teknis operasional model ini menggunakan dua pola yaitu pola penciptaan usaha perorangan dan pola penciptaan usaha kelompok.

$$
\text { Pola usaha perorangan }
$$

dilaksanakan melalui pembinaan dan bimbingan secara terpola dan terencana atas dasar kebutuhan dan peluang usaha yang akan dirintis oleh peserta magang. Pola usaha kelompok dilaksanakan melalui pembinaan dan bimbingan secara terpola dan terencana atas dasar kebutuhan peluang usaha terutama dikaitkan dengan usaha sejenis yang akan dilaksanakan peserta magang secara berkelompok. Sesuai dengan latar belakang bidang ilmu yang ditempuh peserta magang yaitu mahasiswa Fakultas Teknik Jurusan Mesin.

\subsection{Rekruitmen dan seleksi}

Dilakukan untuk mendapatkan calon peserta magang yang sesuai dengan kebutuhan program yaitu memiliki minat tinggi untuk berwirausaha sebagai pilihan karir dan memiliki gagasan usaha yang mudah dikembangkan, mudah dipasarkan dan memiliki prospek yang baik. Mahasiswa yang akan diikut sertakan dalam program magang ini adalah dari Fakultas Teknik Universitas Muhammadiyah Malang . Adapun materi untuk proses seleksi adalah psikotest dan ketrampilan dasar otomotif. 
Jurnal Dedikasi Volume 7, Mei 2010

Test psikologi bertujuan untuk melihat tingkat kemandirian tiap peserta sedangkan test dasar otomotif digunakan untuk melihat ketrampilan peserta sejauh mana mereka menguasai berbagai macam komponen-komponen dalam otomotif.

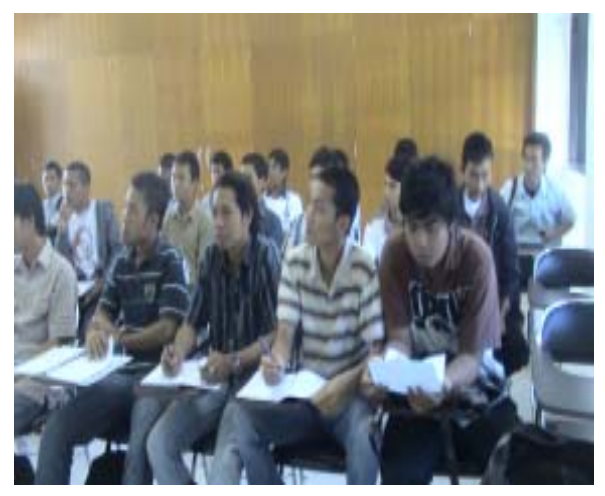

Gambar 4.1. Test Seleksi Calon peserta MKU

\subsection{Pembekalan Peserta Magang}

Pada proses ini peserta magang diberi pembekalan atau materi secara teoritis untuk mempermudah peserta dalam pelaksanaan magang. Pembekalan ini dilakukan selama 2 (dua) hari

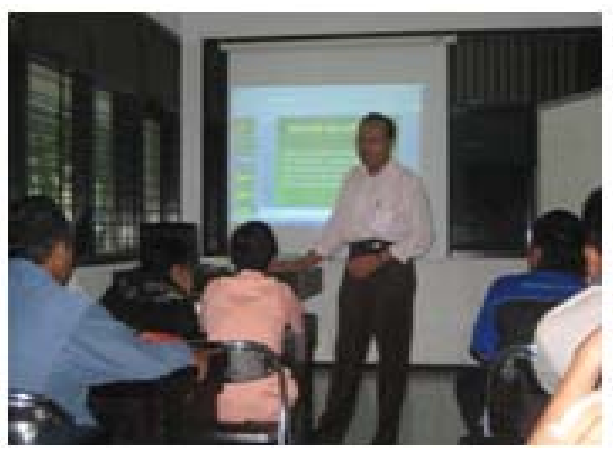

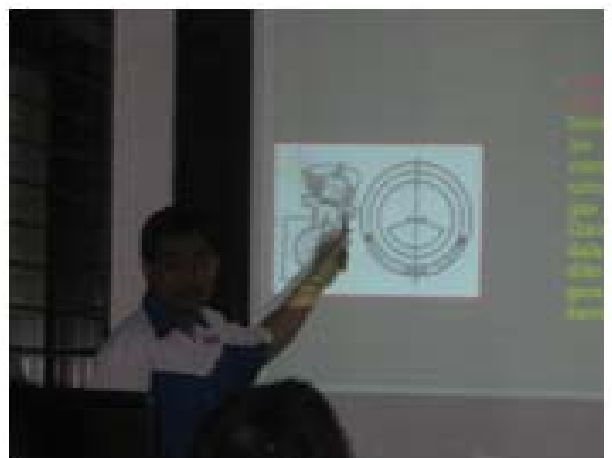

Gambar 4.2: Pembekalan peserta kegiatan

\subsection{Magang}

\section{MKU}

Merupakan tahapan kegiatan penempatan peserta magang yang ditempatkan di industri jasa perawatan kendaraan, dengan tujuan untuk mempelajari teknik-teknik perawatan dan penjualan suku cadang yang baik dan benar, peserta dibidang repeart 6 orang, dibidang

pemasaran 2 orang, dibidang manajemen 2

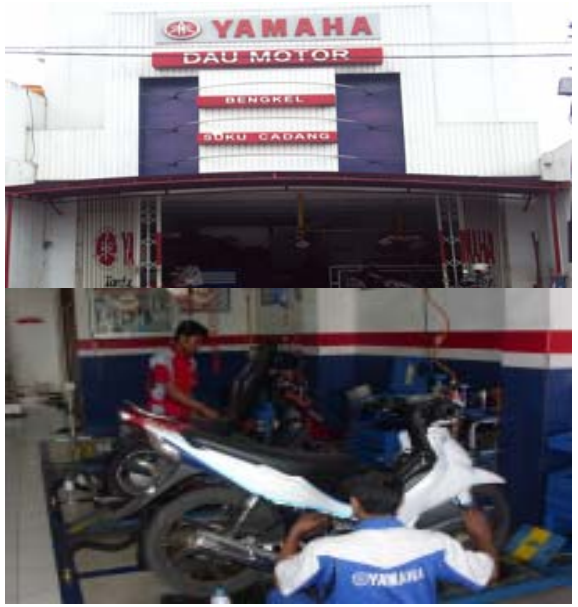

Gambar 4.3: Tempat magang MKU 
Murjito dkk.Magang Kewirausahaan Pada Industri Jasa.

\subsection{Keberlanjutan}

Merupakan tahapan kegiatan peserta magang setelah selesai mengikuti magang. Peserta magang dapat langsung memulai usaha bekerja sama dengan mitra, setelah terlebih dahulu mengajukan proposal kelayakan usaha, baik usaha perorangan maupun kelompok untuk mendapatkan sarana usaha. Usaha yang dirintis diarahkan pada jasa perawatan kendaraan bermotor lebih dahulu, kamudian kalau sudah mempunyai modal baru di tambah usaha jual beli suku cadangnya.

\section{Jadwal Pelaksanaan Kegiatan MKU}

Pelaksanaan magang kewirausahaan ini erlangsung selama 6 bulan. dan dilakukan dalam beberapa tahapan sesuai prosedur yang telah ditetapkan, peserta magang adalaha mahsiswa Fakultas Teknik Jurusan Mesin Universitas Muhammadiyah Malang yang telah menempuh 100 s/d 120 SKS setidaknya mereka sudah semester enam keatas. Adapun jadwal kerja magang kewirausahaan adalah sebagi berikut :

Dalam Pelaksanaan magang, peserta dibagi dalam 2 kelompok dimana masing-masing kelompok beranggota 5 peserta Setiap kelompok mendapat jadual 2 kali dalam seminggu dengan setiap satu kali pertemuan berdurasi 3 jam.

\begin{tabular}{|c|c|c|c|}
\hline No. & Kegiatan & Tempat & Penanggung Jawab \\
\hline 1 & $\begin{array}{l}\text { Kontak: dengan kantor Jasa Perawatan dan } \\
\text { Penjualan suku cadang kendaraen berkaitan } \\
\text { walttu pelaksanaen magang }\end{array}$ & $\begin{array}{l}\text { Kantor Jasa } \\
\text { Perawatan dan } \\
\text { Penjualan suku } \\
\text { cadang }\end{array}$ & Ir. Ali Molkhtar MT, \\
\hline 2 & Pengumuman Penarimaen pesarta & FT-UMM & $\begin{array}{l}\text { Ir. Ali Molkhtar MT, } \\
\text { If. Muriito MT. }\end{array}$ \\
\hline 3 & Pendaftaran peserta magang & FT-UMM & Ir. Ali Molshtar MT, \\
\hline 4 & $\begin{array}{l}\text { - Test Psikologi } \\
\text { - Tes dasar otomotif }\end{array}$ & FT-UMM & $\begin{array}{l}\text { Ir. Ali Molkhtar MT, } \\
\text { Ir. Murjito MT, }\end{array}$ \\
\hline 5 & $\begin{array}{l}\text { Pelaksangen Pembelkalan } \\
\text { - Pembelkalan Orientasi MKU } \\
\text { - Pembelsalan kerwirsusahaen } \\
\text { - Pembelkalan Pengembengan Diri }\end{array}$ & FT-UMM & $\begin{array}{l}\text { If. Ali Molkhtar MT, } \\
\text { If. Murjito MT, }\end{array}$ \\
\hline 6 & $\begin{array}{l}\text { Pelaksansen Magang } \\
\text { - Pengenalan pekerjaen lapangan } \\
\text { - Prosedur dalam perwatan } \\
\text { - Prosedur sistem penjualan } \\
\text { - Pelaksansen perawatan dan panjualan sulu } \\
\text { cadang }\end{array}$ & $\begin{array}{l}\text { Kantor Jasa } \\
\text { Perawatan dan } \\
\text { Penjualan suku } \\
\text { cadang } \\
\text { kendaran }\end{array}$ & $\begin{array}{l}\text { Ir. Ali Molkhtar MT, } \\
\text { If. Murjito MT, } \\
\text { Drs. Wiyono MM, }\end{array}$ \\
\hline 7 & Monitoring dan evaluasi & $\begin{array}{l}\text { Kantor Jasa } \\
\text { Perawatan dan } \\
\text { Penjualan suku } \\
\text { cadang } \\
\text { kendargen }\end{array}$ & $\begin{array}{l}\text { Ir. Ali Molkhtar MT, } \\
\text { Ir. Murjito MT, } \\
\text { Drs. Wiyono MM, }\end{array}$ \\
\hline 8 & $\begin{array}{l}\text { Pernbuatan laporan magan dan rencana } \\
\text { wirausaha }\end{array}$ & $\begin{array}{l}\text { FT-UMM dan } \\
\text { tempat magang }\end{array}$ & $\begin{array}{l}\text { Ir. Ali Molkhtar MT, } \\
\text { Ir. Murjito MT, } \\
\text { Drs. Wiyono MM, }\end{array}$ \\
\hline
\end{tabular}

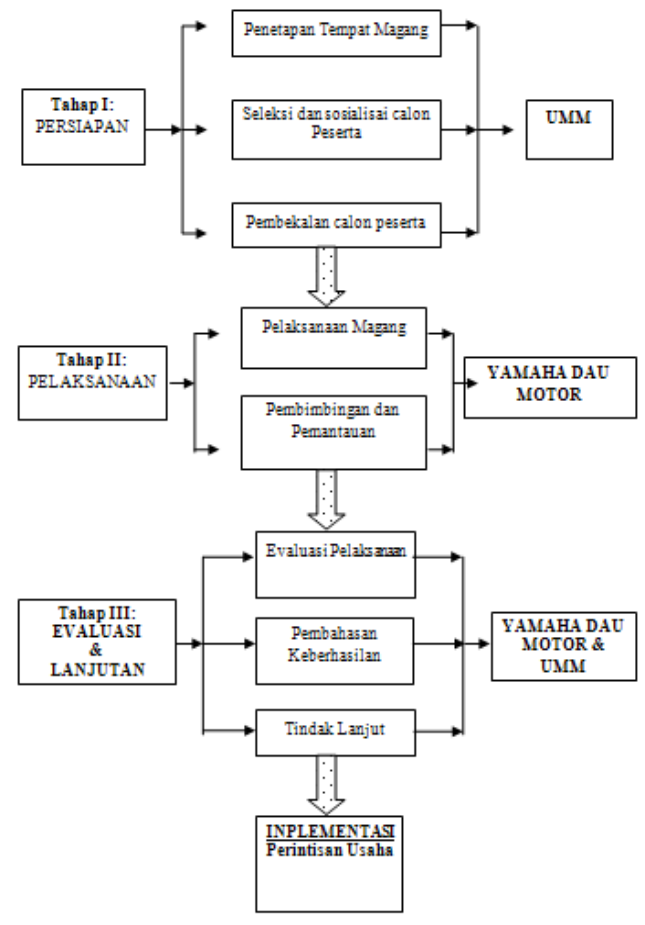


Jurnal Dedikasi Volume 7, Mei 2010

\section{EVALUASI DAN PEMBAHASAN PELAKSANAAN KEGIATAN}

\section{Manfaat dan ketercapaian tujuan kegiatan}

Proses magang kewirausahaan di industri jasa perawatan dan penjualan suku cadang kendaraan bermotor dilakukan melalui beberapa tahapan :

\section{a. Dari Industri Mitra}

- Perusahaan mitra tempat magang merasakan manfaat dari kegiatan magang oleh mahasiswa

- $\quad \mathrm{e}$ e a k u k a $\mathrm{n}$ pendampingan dan bimbingan tentang penggunaan alat atau tool kit yang ada di bengkel

- Melalukan bimbingan dan pendampingan pada peserta tentang SOP (Standart Operasional Pekerjaan) mekanik

- Melalukan bimbingan dan pendampingan pada peserta tentang SOP (Standart Operasional Pekerjaan) pelayanan barang/spare part.

\section{b. Dari Mahasiswa Peserta MKU}

- Mahasiwa peserta program magang mendapat pengetahuan tentang teknik otomotif dan perawatannya.

- Mahasiswa dapat pengetahuan kapan sepeda harus dirawat dan diservis.

- Mahasiswa dapat pengetahuan tentang kapan kendaraan harus ganti spare part dan oli

- Mahasiwa dapat bagaimana menjual spare part/ suku cadang dan kode-kodenya.

- Mahasiswa mempunyai jiwa wirausahawan

\section{c. Perguruan Tinggi Pelaksana}

- Jumlah mahasiswa yang terlibat dalam MKU 10 Orang

- Mahasiswa peserta dapat pengetahuan interprener sip/ kewirausahaan

- Dapat menumbuh kembangkan budaya kewirausaan di kalangan kewirausahaan serta menyediakan lapangan kerja di lingkungan mereka tinggal.

- Peserta magang telah mendapatkan wacana pengetahuan perawatan kendaraan bermotor dan sistem managemen dalam mengelola usaha mulai SDM sampai dengan keuangan serta sistem marketing atau penjualan suku cadang kendaraan bermotor yang diterapkan di tempat MKU. 
Murjito dkk.Magang Kewirausahaan Pada Industri Jasa.

mahasiswa untuk mendorong terciptanya wirausaha baru

\section{Penerapan metode penyelesaian masalah industri/pengusaha}

Pelaksanaan kegiatan dibagi dalam tiga tahap yaitu, 1). Persiapan, 2). Pelaksanaan, 3) evaluasi dan tindak lanjut. Pada tahapan ini tim menetapkan tempat magang, sesuai dengan kebutuhan dan prospek ke depan, maka dipilih YAMAHA DAU MOTOR, sebagai tempat magang. Peserta MKU adalah hasil seleksi berdasarka prestasi test dan praktek yang diperoleh sebelumnya, yaitu dari 25 peminat diseleksi dan ditetapkan menjadi 10 peserta.

3. Luaran kegiatan dan perwujudan indikator pencapaian tujuan kegiatan

Indikator keberhasilan program MKU berikut ini didasarkan atas pengamatan terhadap peserta magang, antara lain :

- Peserta magang 50\% mempunyai wawasan kewirausahaan dilihat dari hasil psikotest.

- Peserta magang mampu mengaplikasikan hasil magang kewirausahaan di laboratorium konversi energi dan otomitif jurusan mesin Universitas Muhammadiyah Malang.

- Peserta magang akan mengembangkan hasil kegiatan magang

\section{Kesimpulan}

\section{Kesimpulan}

1. Pemagangan yang dilakukan di YAMAHA DAU MOTOR memberikan bekal ketrampilan otomotif yang sangat berarti kepada seluruh peserta dalam ini peserta dapat mengetahui dan mengerti dengan jelas bagai mana mengelola bengkel otomotif dan teknik-teknik otomotif.

2. Pemagangan telah memberikan pengetahuan praktis tentang manajemen usaha jasa otomotif dan menjadikan seluruh peserta terbuka wawasan kewirausahaannya dan lebih percaya diri untuk menghadapi tantangan maupun resiko bisnis otomotif.

3. Pihak Usaha mitra atau bengkel tempat magang merasa senang dengan model pemagangan ini, karena peserta telah dibekali teori maupun praktek sesuai dengan apa yang akan dihadapi di bengkel tempat MKU di laksanakan selama dua bulan di YAMAHA DAU MOTOR.

4. Seluruh peserta sangat berminat merintis dan mengembangkan usaha jasa perbengkelan dan lembaga pelatihan di daerahnya masing-masing setelah mereka lulus. Yang didahului dengan pembuatan rencana usaha (bisnis plan) yang telah dirancang bersama antara peserta , dosen pembimbing, pihak industri dan pihak pakar yang terkait. 
Jurnal Dedikasi Volume 7, Mei 2010

\section{Tindak Lanjut Kegiatan}

Tindak lanjut yang dilakukan dalam program ini adalah komitmen peserta dalam mengembangkan wirausaha dan usaha baru yang telah didapat dalam pemagangan. Komitmen peserta ini dapat diaplikasikan dalam mendirikan mendirikan bengkel otomotif kususnya sepeda motor, dalam perkembangannya sepada motor semakin tahun semakin banyak. Sehingga menjadi peluang baru untuk mendapat pekerjaan.

\section{DAFTAR PUSTAKA}

1. Anonim. 1999. Panduan program Pengembangan Budaya Kewirausahaan di Perguruan Tinggi. Ditbinlitabmas Ditjen DIKTI, Jakarta

1. Effendy, M dan Fdjar, A. M. 1998 Dunia Perguruan Tinggi dan Kemahasiswaan. Pusat Penerbitan Universitas Muhammadiyah Malang

3. Panduan Pengelolaan Program Hibah DP2M Ditjen Dikti - Edisi VII

4. Manajemen Kewirausahaan
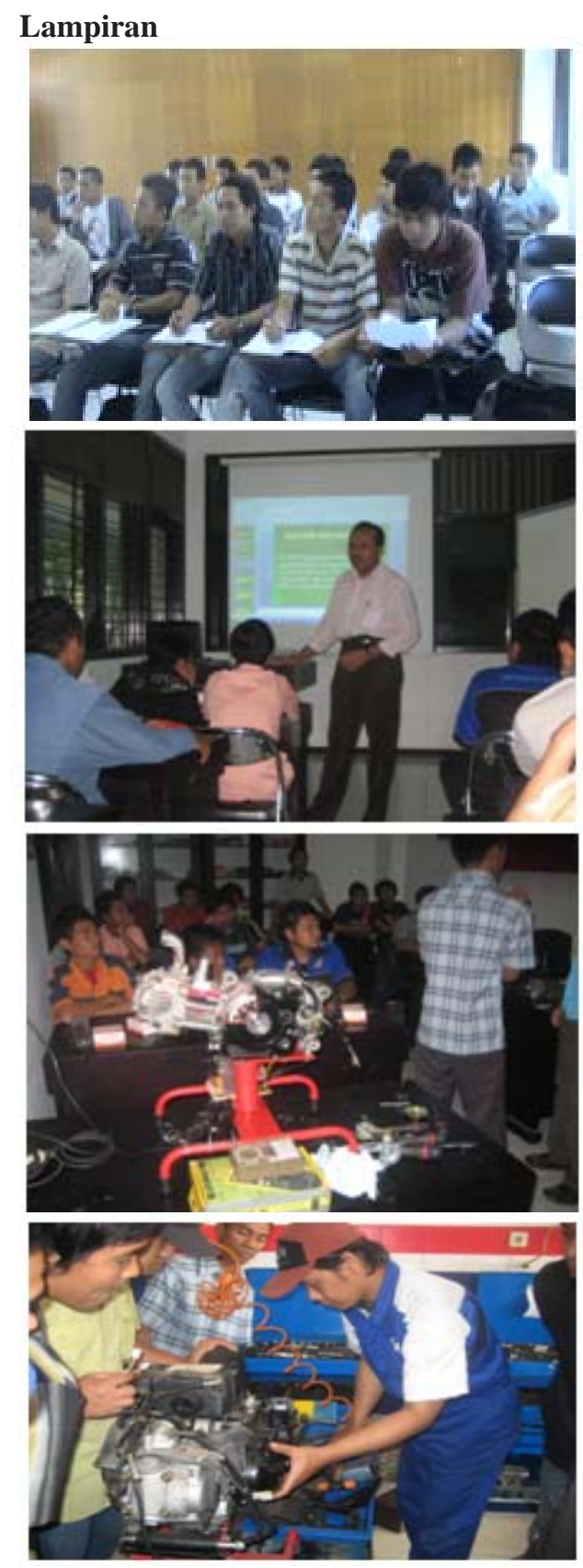
Murjito dkk.Magang Kewirausahaan Pada Industri Jasa. 